International Journal of Social Science and Economic Research

ISSN: 2455-8834

Volume: 05, Issue: 09 "September 2020"

\title{
TOURISM AND EMPLOYMENT IN NEPAL
}

\author{
Men BahadurAdhikari \\ Lecturer, Department of Economics, Mahendra Multiple Campus, Nepalgunj, Nepal \\ DOI: 10.46609/IJSSER.2020.v05i09.012 URL: https://doi.org/10.46609/IJSSER.2020.v05i09.012
}

\begin{abstract}
Tourism has become an engine of Nepalese economy for the generation of income and employment. The time series secondary data of periods 2008/09 to 2018/19, collected from different sources has been used for the study. The trend of tourist arrivals in Nepal has been increasing and 1173072 international tourists visited Nepal in 2019, which is an increment of 24.8 percent from 2018 . Out of them, 82.63 percent of the tourists arrived using air services and rest of the 17.37 percent used land services. Among them, 60 percent tourists visitedfor the sake of entertainment, 16 percent for trekking/ mountaineering, 14.4 percent for pilgrimage, and 9.6 percent for other purposes. The average length of stay per touristin 2019, and average expenditure per tourist per day in 2017/18 in Nepal were 12.4 days and 54 USD respectively.India, China, America, Sri Lanka and UK were the top 5 countries in terms of tourist arrivals in Nepal in 2019. The foreign currency earning has slowly increased and reached to 67095 Million Rupees in the year 2017/18. This amount contributes to 5 percent of total foreign currency earning and 2.2 percent of GDP. According to Travel and Tourism Council Data, the travel and tourism sector provided direct employment to 453.9 thousand individuals in 2018, which is 2.9 percent of total employment. In general, the tourism activities in Nepal seemswell, but there is stagnation in the major tourism indicators in the view point of prosperous tourism, such as growth rate of tourist arrival, average length of stay, expenditure per tourist per day, etc. Therefore, in order to promote the travel and tourism sector, the Government of Nepal and related stakeholders ought to work to reform basic infrastructures and other facilities.
\end{abstract}

Key-Words:- Tourism activities, Tourist arrivals, Purpose of visit, Length of stay, Foreign exchange.

\section{INTRODUCTION}

Tourism is generally defined as the act and process of spending time away from home in search of recreation, relaxation, and pleasure while making use of the commercial provision of services. In other words, tourism is the activity of traveling for visiting, sightseeing of interesting things, 


\section{International Journal of Social Science and Economic Research}

ISSN: $2455-8834$

Volume: 05, Issue: 09 "September 2020"

trekking, boating, skating, and spending leisure time in beautiful places outside the domestic area for some days. According to the UN World Tourism Organization, "Tourism is a collection of activities, services, and industries which deliver a travel experience comprising transportation, accommodation, eating and drinking establishment retail shops, entertainment businesses and other hospitality services provided for individuals or groups travelling away from home." A traveler is someone who is making a visit to a destination outside his/her usual environment for less than a year with any purpose such as holidays, leisure and recreation, business, health, education, religion or any other purposes.

Tourism is not just a global holiday or air travel but it includes a visit to hill stations, snow covered hills, beaches or a long journey, etc. It also comprises of people who travel for conferences, researches, seminars, business related activities, etc. These travelers use all forms of transport and all kinds of tourism facilities such as railways, ships, airlines, etc. Any activity that is ensured for necessary accommodation and arrangement for a tourist is called a tourism industry. Tourism industry includes the whole business activities that provide facilities for tourists like hotel and restaurant, travel agency, trekking agency, entertainment business, and other related activities. Tourism industry is termed as 'Peace Industry' or 'Smokeless Industry'.

In short, we can say that tourism is the movement of people to destinations outside the area where they live and work. Tourism is not only a travel to a particular place, but it also includes the activities performed during travel to meet their needs. Thus, tourism includes the activities and services required to meet the needs of the tourists. The tourism industry plays a vital role in promoting economy directly or indirectly. Tourism industry is a service oriented industry which is growing rapidly all over the world.

Nepal is a small landlocked mountainous country which is ranked among the poor countries in the world. Nepal is a small, but beautiful country, and the beautyisdiversified all over the country. So, there is an enormous possibility of development of tourism industry in Nepal. The possibility of tourism in Nepal is aided by the presence of variety of interesting things to see and do. Nepal is the home to the world's highest mountains, historic cities, cultural and climatic varieties.Religious places such as Lumbini, Pashupatinath, Muktinath, forests with rare birds and animals, lakes, rivers, rural settlement are equally important aspect of tourism in Nepal. In Nepal, the most popular tourist activities are mountaineering, water rafting, and trekking. Therefore, tourism has a great potential to uplift the national economy. Today, tourism has become one of the major economic aspects of Nepalese economy for the generation of income, employment, and foreign exchange.

In ancient time, tourism just meant traveling, but it became much more than traveling after spas and grand tours were developed in the $17^{\text {th }}$ and $18^{\text {th }}$ century. The movement of the tourism sector 


\section{International Journal of Social Science and Economic Research}

ISSN: $2455-8834$

Volume: 05, Issue: 09 "September 2020"

has been enhanced via jet airplanes and charter flights from the mid of $20^{\text {th }}$ century. Inthe past, tourism was only experienced by high- class society because at that time travel was booked for only an upper class and royalty due to their ability to travel. Changing aspects of tourism since ancient time, travel and tourism have been an important social activity of human beings (Adhikari,2019).

The history of tourism in Nepal is very short and Nepal was almost separated from the world up to 1951. After the establishment of democracy in 1951, foreigners were permittedfor tourism by the Nepal Government by providing them a tourist visa. Tourism development of Nepal began afterreceiving a membership of international travel association in 2008 B.S. The tourism development board and tourism development committee were established in 2013 and 2014 B.S. respectively. The tourism development committee was converted into the tourism department in 2015 B.S. The ministry of tourism was established in 2034 in Nepal (Pant et al,2018). Nowadays, Nepal Tourism Board which was established in 1998 is a national tourism organization of the country that acts as a model of public-private partnership to develop and make Nepal as an attractive tourist destination.

There are various types of tourism activities for tourists who want to explore Nepal. Among those different tourism activities, adventure tourism is a leading activity in Nepal. It involves the exploration of remote places where travellers can feel unexpected sensation where he/she is physically active at that time. Adventure tourism includes different activities like mountaineering, trekking, rafting, cannoning, bungee, paragliding,etc. In cultural tourism, travelers want to acquire knowledge about different art, music, fashion, festivals, etc. Ecotourism also known as wildlife tourism involves visiting to protected natural areas and watching birds and animals. In religious tourism, tourists attend religious duties and visit religiously important places. Recreational tourism means the activities for recreational purpose such as change and rest.Village tourism involves traveling and arranging tours in order to popularize various village destinations.

Tourism may be important activity for the generation of income and employment in Nepal. There are alot of possibilities of tourism development in Nepal. Nepal is famous for its natural beauty, geographical diversity, cultural and religious diversity, climatic variety, bio-diversity with rare birds and animals, and hospitable and tourist friendly people (Subedi,2018). The climate of Nepal is very suitable for tourists from any country as it has different climatesto offer based on the geographical location. Nepal is also rich in bio-diversity asit is home to various rare species of Flora and Fauna. Nepal is comparatively a peaceful country and it has cultural and religious tolerance and Nepalese people are hospitable. Again, Nepal is a cheap tourist destination country judging from the point of view of travel and settlement cost mainly due to low exchange value of Nepalese currency. Nepal is famous for its natural beauty and it houses 
International Journal of Social Science and Economic Research

ISSN: 2455-8834

Volume: 05, Issue: 09 "September 2020"

the world'shighest mountain peak 'The Mount Everest' and other 8highest peaks of the world, conservation areas with rare birds and animals, rivers, rivulets, waterfalls and lakes, wonderful trekking routes, and welcoming people. Nepal is also rich in cultural and religious diversity as there are around 125 ethnic groups with varying culture and customs (Subedi,2018). The beauty and richness of culture can be seen in different original festivals. Different pilgrimage sitesare another basis for the developmentof tourism in Nepal. Lumbini,famous for the birthplace of Gautam Buddha, who is known as a Light of Asia, lies in Nepal.Similarly, there are various religious places according to Hindu beliefs such as Pasupatinath, Muktinath, Krishna Temple, Janaki Temple, and other various religious places. Nepal is also attractive tourist destination for mountaineers, rock climbers, and adventure seekers. Being a country of villages, tourism can be developed by promoting the concept of homestay in Nepal for those who want to know and explore the village.

Now, tourism is an important source of foreign exchange in Nepal asapproximately 4.8 percent of the total foreign exchange came from tourism in first eight months in 2018/19. In 2019, 1173072 international tourists visited Nepal. This represents a 24.78 percent annual increase than in 2018. Out of the total tourist arrivals, almost 53 percent of the tourists were from the five countriesIndia, China, USA, Sri Lanka, and UK (MoCTCA, 2020).

\section{STUDY OBJECTIVES}

The present study is related to tourism and its contribution on employment generation in Nepal. Especially, international tourists were taken into account during the study. Thus, the general objective of this study is to reflect the present scenario of tourism in Nepal. The specific objectives of this study are as follows:

To -analyze the trends of tourist arrival in Nepal.

To -examine the contribution on income and employment by tourism in Nepal.

\section{METHODOLOGY}

The present study shows the general trend of tourist arrival and employment generation by tourism sector in Nepal. The present study is based on secondary data and information which is collected from various reliable sources. The data and information has also been obtained from published and unpublished documents and articles. The study is mainly descriptive in nature and the collected data are analyzed using appropriate statistical tools. This article depends on the secondary data of past eleven Nepalese fiscal years i.e. 2008/09 to 2018/19. The necessary data were collected from the different government publications such as publication of Economic Survey of Ministry of Finance (MoF), Ministry of Culture, Tourism and Civil Aviation 


\section{International Journal of Social Science and Economic Research}

ISSN: $2455-8834$

Volume: 05, Issue: 09 "September 2020"

(MoCTCA), Periodic Plans of National Planning Commission (NPC). Some of the data used in the study were also collected from the publications of Nepal Rastra Bank (NRB). Similarly, some data were also collected from the publication and website of the World Bank (WB), United NationWorld Tourism Organization (UNWTO), etc.

\section{TOURISM IN NEPAL}

Nepal is a small, but beautiful mountainous country. Although it has a small territory, the landscape of Nepal is diverse ranging from plain terai in south and high hills and mountains in the north. There are 8 high mountain peaks, including the highest, theMount Everest. The climatic condition of Nepal also varies according to topography having hot and humid climatic condition in terai, pleasant warm temperate in hills, and alpine climate in the high mountains. Natural beauty, cultural varieties, bio-diversity with rare wildlife, and archeological beauties are the main attraction for the tourist in Nepal. Various types of rivers, lakes, waterfalls, rural villages, trekking for adventure, sports like paragliding, rafting, and canoeing and home stay are the other attraction for visitors in Nepal.

The history of tourism in Nepal started after the successful expedition of Tenzing Norgay Sherpa and Sir Edmund Hillary to reach the top of Mount Everest in 1953, thereafter the foreign tourists started to visit the country slowly (Shrestha et al, 2012). Thousands of visitors are coming to Nepal to explore its natural beauty and to observe the rich cultures and traditions related to diverse religious communities. In the review of government effort for the attraction of visitors in Nepal, His Majesty's Government had declared the year 1998 as 'Visit Nepal 98' to present Nepal as a special tourist destination country. Again, the government of Nepal decided to launch a national tourism campaign, 'Nepal Tourism Year 2011'. The tourism sector has experienced a continuous expansion and diversification becoming one of the largest economic sectors of Nepal.

The Government of Nepal has also declared, 'Visit Nepal 2020' to this year in order to promote the country's tourism industry with the aim of bringing two million tourists in 2020, but the declaration of the Government has been completely affected by COVID-19 that has spread worldwide. Because of the travel bans, country lockdowns, and fear of the Corona Virus, no one wants to leave their home. So, the tourism industry has been badly affected dueto the absence of visitors. The tourist related business organizations in the country are having a hard time and experiencing an economical downfall.

\section{TOURIST ARRIVALS IN NEPAL}

The modern history of tourism development in Nepal began after the establishment of democracy in 1951. Nepal has its doors opened for foreigners who want to visit Nepal after that time. The record of tourist arrivals has been maintained by Department of Tourism from 1962. 
International Journal of Social Science and Economic Research

ISSN: 2455-8834

Volume: 05, Issue: 09 "September 2020"

Total 6179 foreign tourists had visited to Nepal in the year 1962. The international tourist arrival in Nepal has generally seen an increasing trend except in some years. Just after a decade, in 1972, the tourist arrival in Nepal was 52930. Similarly, in the following decades 1982, 1992, and 2002 the total number of tourist arrivals increased to 175448, 334353, and 275468 respectively. The tourist arrivals reached to 803092 in the year 2012 (Shrestha et al, 2012). The number of tourist arrivals seemed to have affected due to the ongoing Maoist insurgency during the period 1996 to 2006 because of internal issues. Again, the tourist arrival was decreased in 2015 due to earthquake. After 2015, the number of tourist arrivals has remarkably increased. In the current year 2020, the number of incoming tourist arrivals was badly affected by Corona Virus.The trend of tourist arrivals during the period of 2004 Mid-January to 2019 Mid-January is presented below:

\section{Tourist Arrivals and Length of Stay}

$\begin{array}{lccccr}\text { Years } & \begin{array}{r}\text { Number of } \\ \text { Tourists }\end{array} & \begin{array}{r}\text { Tourists Arrival } \\ \text { byAir(Number) }\end{array} & \begin{array}{r}\text { Tourists Arrival by } \\ \text { Land(Number) }\end{array} & \begin{array}{r}\text { Average Length } \\ \text { of Stay per } \\ \text { Tourist }\end{array} & \begin{array}{r}\text { Annual Growth } \\ \text { Rate ofTourist } \\ \text { Arrivals(in \%) }\end{array} \\ \text { 2004Mid- Jan } & 338132 & 275428(81.46) & 62704(18.54) & 9.6 & 22.7 \\ \text { 2005Mid- Jan } & 385297 & 297335(77.17) & 87962(22.83) & 13.5 & 13.9 \\ \text { 2006Mid- Jan } & 375398 & 277346(73.88) & 98052(26.12) & 9.1 & -2.6 \\ \text { 2007Mid- Jan } & 383926 & 283819(73.93) & 100107(26.07) & 10.2 & 2.3 \\ \text { 2008Mid- Jan } & 526705 & 360713(68.48) & 165992(31.52) & 12.0 & 37.2 \\ \text { 2009Mid- Jan } & 500277 & 374661(74.89) & 125616(25.11) & 11.8 & -5.0 \\ \text { 2010Mid- Jan } & 509752 & 379622(74.47) & 130130(25.53) & 11.6 & 1.9 \\ \text { 2011Mid- Jan } & 602867 & 448800(74.44) & 156067(25.56) & 12.7 & 18.3 \\ \text { 2012Mid- Jan } & 736215 & 545221(74.06) & 190994(25.94) & 13.1 & 22.0 \\ \text { 2013Mid- Jan } & 803092 & 598258(74.49) & 204834(25.51) & 12.9 & 9.1 \\ \text { 2014Mid- Jan } & 797616 & 594848(74.58) & 200768(25.42) & 12.5 & -0.7 \\ \text { 2015Mid- Jan } & 790118 & 585981(74.16) & 204137(25.84) & 12.4 & -0.9 \\ \text { 2016Mid- Jan } & 538970 & 407412(75.59) & 131558(24.41) & 12.8 & -31.8 \\ \text { 2017Mid- Jan } & 753002 & 572563(76.04) & 180439(23.96) & 13.4 & 39.7 \\ & & & & & \\ \end{array}$


International Journal of Social Science and Economic Research

ISSN: 2455-8834

Volume: 05, Issue: 09 "September 2020"

2018Mid- Jan

940218

760577 (80.89)

179641(19.11)

12.6

24.9

2019Mid- Jan

1173072

$969287(82.63)$

203785(17.37)

12.4

24.8

Average

75.71

24.29

12.04

10.99

Source:- Economic Survey 2018/19, Ministry of Finance, Government of Nepal.

The available means of transportation in Nepal are the air and bus services. More than 80 percent tourists had used air services in order to visit Nepal in the year 2004, 2018 and 2019 and more than 30 percent tourist had used bus services in the year 2008. During the study period, it is found that more than 75 percent of the tourists used air services and less than 25 percent used bus services in an average.The above table shows the general fluctuation in the trends of tourist arrivals in the study periods. For examples, the number of tourists arrivals increased by 37.2 percent and 39.7 percent in the year 2008 and 2017 respectively. The number of tourist arrivals decreased by 31.8 percent in the year 2016 due to the earthquake of 2015 . The average growth rate of tourist arrivals in Nepal was 10.99 percent in the study periods. The length of stay per tourist in the country has vital role in tourism development. Higher the length of stay, the more beneficial it is for the country. In Nepal, the length of stay is not so long and it is recorded 9.1 day to 13.4 day during the study periods. The average length of stay of tourist in Nepal was 12.04 days in the study periods, whereas, in India, the average length of stay per visitor was calculated to be 22.7 day in 2018 .

The analytical data about the trend of tourist arrivals in Nepal from the Year 2004 Mid - January to 2019 Mid - January has been picturized in the Plot Diagam given below:

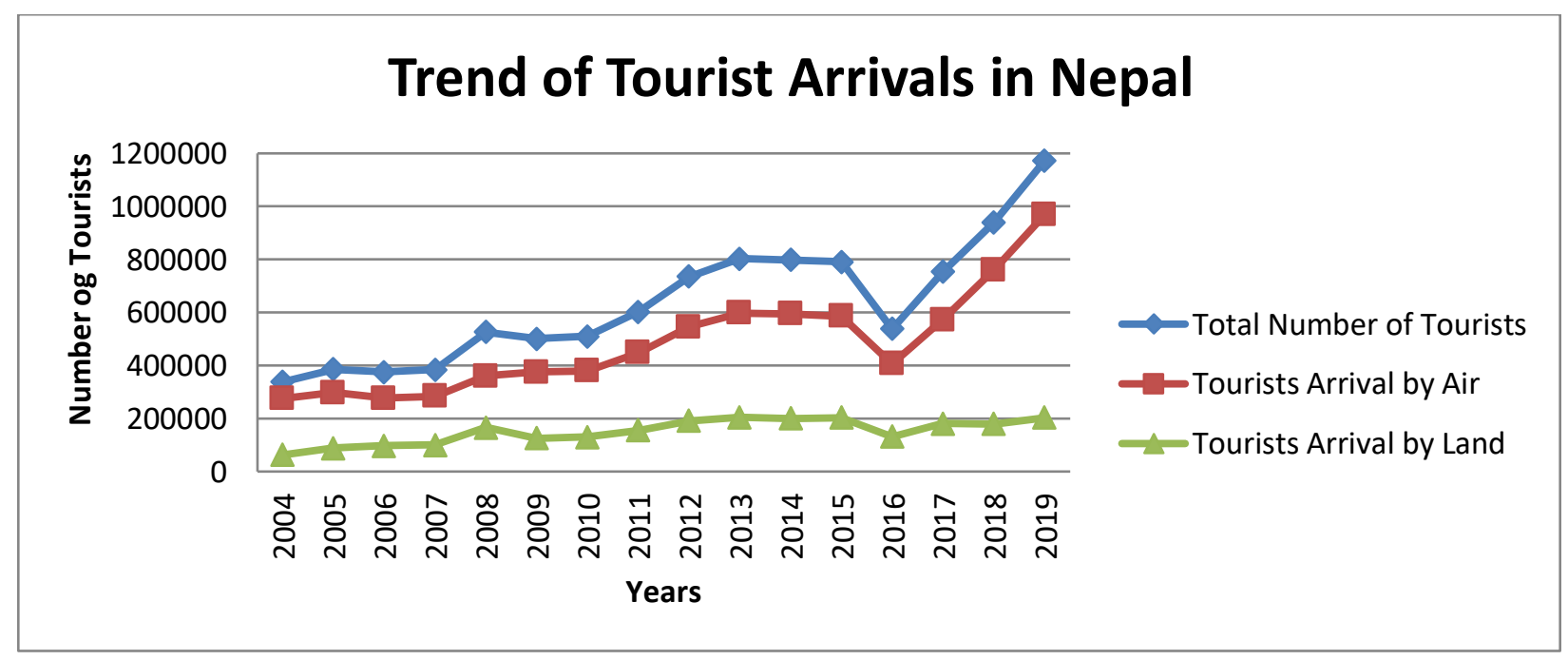


International Journal of Social Science and Economic Research

ISSN: 2455-8834

Volume: 05, Issue: 09 "September 2020"

\section{TOURIST ARRIVALS BY MAJOR COUNTRIES}

Today, the tourism movement has become a global activity. According to UN World Tourism Organization, in 2018, the country France was the leading country in the world, followed by Spain, USA and China respectively. In collective reference, China was the most visited country among Asia-Pacific countries, Morocco among African nations, USA in among American nations, andUAEamong Middle-East countries. The famous tourist destination, Switzerland ranked at $38^{\text {th }}$ position in the world. Similarly, among the South Asian countries, Sri Lanka was ranked at $21^{\text {st }}$, India at $23^{\text {rd }}$, and Nepal at $116^{\text {th }}$ place in the world. The number of tourist arrivals by different countries in the year 2007 to 2019 is presented below:

\section{Number of Tourist Arrivals by Major Nationalities}

\begin{tabular}{|c|c|c|c|c|c|c|}
\hline Country & $\begin{array}{c}2015 \\
\text { Mid-Jan }\end{array}$ & $\begin{array}{c}2016 \\
\text { Mid-Jan }\end{array}$ & $\begin{array}{c}2017 \\
\text { Mid-Jan }\end{array}$ & $\begin{array}{c}2018 \\
\text { Mid-Jan }\end{array}$ & $\begin{array}{c}2019 \\
\text { Mid-Jan }\end{array}$ & $\begin{array}{c}\text { Growth } \\
\text { Rate in } 2019 \\
\text { (in percent) }\end{array}$ \\
\hline Australia & $24516(3.10)$ & $18619(3.45)$ & 25507 (3.39) & $33371(3.48)$ & $38429(3.28)$ & 15.16 \\
\hline Bangladesh & $21851(2.78)$ & $14831(2.75)$ & $23440(3.11)$ & $2906(3.03)$ & $26355(2.25)$ & -9.31 \\
\hline Canada & $11610(1.47)$ & 8398 (1.56) & $12491(1.66)$ & $15105(1.58)$ & $17317(1.48)$ & 14.64 \\
\hline China & $123805(15.67)$ & 66984 (12.43) & 104005 & 104664 (10.90) & $153633(13.10)$ & 46.79 \\
\hline France & $24097(3.05)$ & $16405(3.04)$ & $20863(2.77)$ & $26140(2.73)$ & $31810(2.71)$ & 21.69 \\
\hline Germany & $18028(2.28)$ & $12728(2.36)$ & $23812(3.16)$ & 29918 (3.12) & $36879(3.14)$ & 23.27 \\
\hline India & $135343(17.13)$ & 75124 (13.94) & $118249(15.70)$ & $160832(16.78)$ & $194323(16.57)$ & 20.82 \\
\hline Italy & 1034 (1.13) & 5609 (1.04) & $9911(1.32)$ & $11840(1.24)$ & $15342(1.31)$ & 29.58 \\
\hline Japan & $25829(3.27)$ & $17616(3.27)$ & 22979 (3.05) & $27326(2.85)$ & $29817(2.54)$ & 9.12 \\
\hline S. Korea & 23205 (2.94) & $18112(3.36)$ & $25171(3.34)$ & $34301(3.58)$ & 37218 (3.17) & 8.50 \\
\hline Myanmar & - & - & $25769(3.42)$ & $30852(3.22)$ & $41402(3.53)$ & 34.20 \\
\hline Malaysia & - & - & - & $18284(1.91)$ & $22833(1.95)$ & 24.88 \\
\hline Netherlands & $12320(1.56)$ & 7515 (1.39) & $11453(1.52)$ & $13393(1.40)$ & $15352(1.31)$ & 14.63 \\
\hline Spain & $13110(1.66)$ & $6714(2.34)$ & 12255 & $15953(1.66)$ & $20214(1.72)$ & 26.71 \\
\hline Thailand & - & - & $26722(3.55)$ & $39154(4.08)$ & $52429(4.47)$ & 33.90 \\
\hline Sri Lanka & $37546(4.75)$ & $44367(8.23)$ & $57521(7.64)$ & $45361(4.73)$ & $69640(5.94)$ & 53.52 \\
\hline
\end{tabular}


International Journal of Social Science and Economic Research

ISSN: 2455-8834

Volume: 05, Issue: 09 "September 2020"

$\begin{array}{lrrrrrr}\text { USA } & 49830(6.31) & 42687(7.92) & 53645(7.12) & 79146(8.26) & 91895(7.83) & 16.11 \\ \text { UK } & 36759(4.65) & 29730(5.52) & 46295(6.15) & 51058(5.33) & 63466(5.41) & 24.30 \\ \text { Others } & 221922(28.09) & 153531(28.49) & 132914(17.65) & 192774(20.11) & 214718(18.30) & 11.38 \\ \text { Total } & 790118(100) & 538970(100) & 753002(100) & 9885329(100) & 1173072(100) & 22.38\end{array}$

Source:-Economic Survey 2018/19, Ministry of Finance, Government of Nepal.

In the above table, India, China, America, Sri Lanka and UK are the top 5 countries in terms of tourist arrivals in Nepal. Neighboring country India has become the top country for tourist arrivals in Nepal. A total of 194323 Indian tourists visited to Nepal in 2019, which is 16.57 percent, while 153633 Chinese tourists visited to Nepal andgave China the second position in this ranking. Similarly, America stood at third position in the year 2015, 2018, and 2019, but the position was taken by Sri Lanka in the year 2016 and 2017. Likewise 63466 British tourists visited the country and UK remained at the $5^{\text {th }}$ position. Among the 18 major tourist arrival countries, the number of tourists from the Bangladesh declined in 2019. The number of tourist arrivals from the other remaining countries had increased in 2019. The annual growth rate of tourist arrivals from Sri Lanka was 53.32 percent, followed by China with 46.79 percent, Myanmar with 34.2 percent, and Thailand with 33.9 percent in 2019.

The statistical data describing tourist arrivals in Nepal by top 5 nationalities from the year 2015 Mid - January to 2019 Mid - January is represented in the bar diagram constructed below:

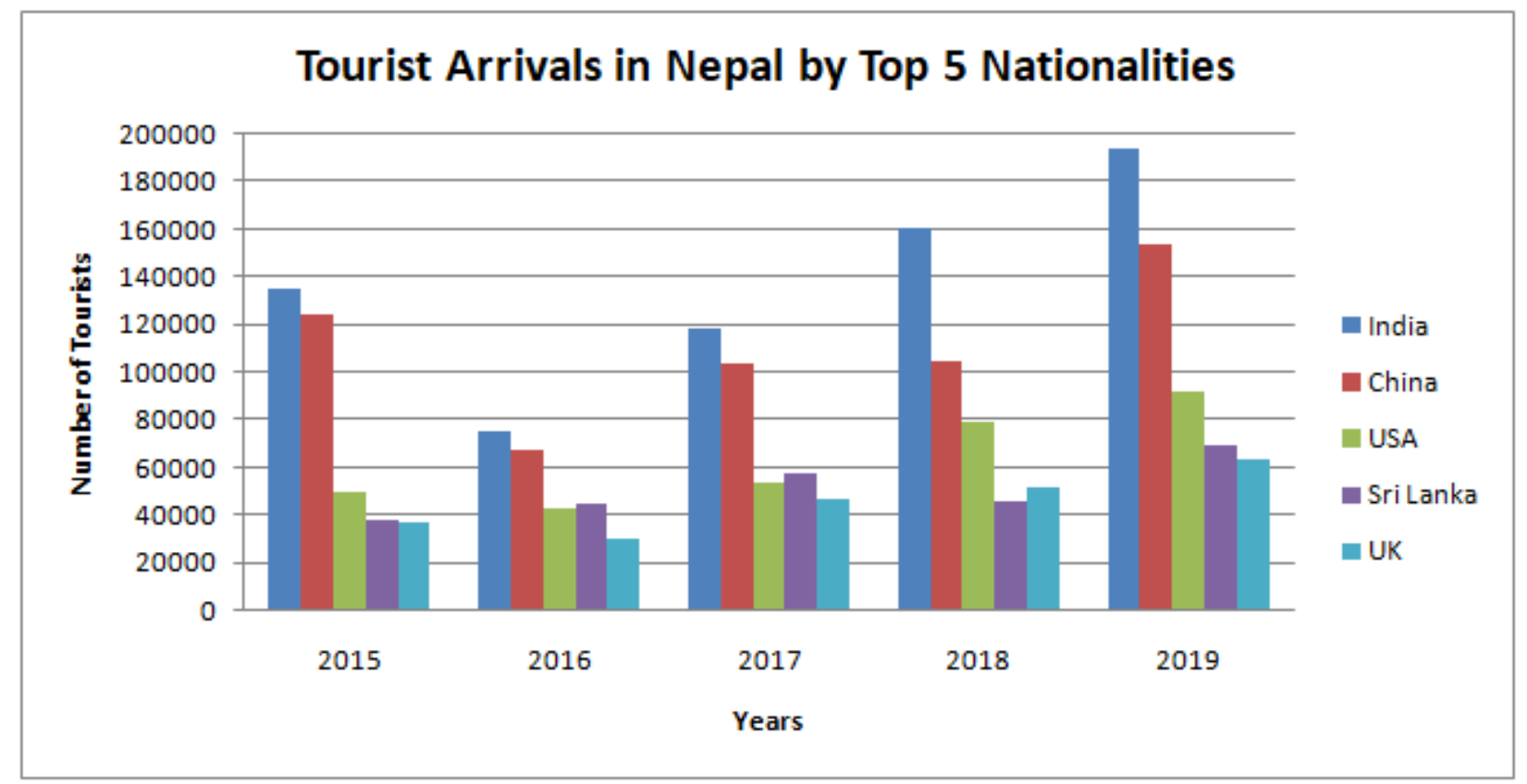


International Journal of Social Science and Economic Research

ISSN: 2455-8834

Volume: 05, Issue: 09 "September 2020"

\section{TOURIST ARRIVAL BY PURPOSE OF VISIT}

There is no meaning of travel or journey without any purpose, and the travel would not be taken either. When the purpose of visit comes into consideration, there are many purposes such as holiday and leisure recreation, education and training, health and medical care, religion/pilgrimage, business,etc. According to Tourism Statistics 2019, total 81.72 percent of foreign tourist travelled with the purpose of pleasure/holiday in Sri Lanka and 62.4 percent of tourist with the same purpose visited India in 2018. In global context, in 2018, the tourists that travelled with the purpose of holidays and leisure recreation were 56 percent, followed by a total of 27 percent with purpose of visiting friends and relatives, health, religion, and 13 percent traveled with business and professional purposes. The percentage share of tourist arrivals in Nepal by purpose of visit is presented below:

\begin{tabular}{|c|c|c|c|c|c|c|c|c|c|c|c|}
\hline$\stackrel{\circlearrowright}{\beth}$ & 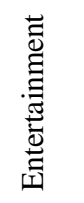 & 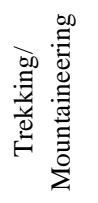 & 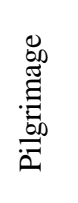 & 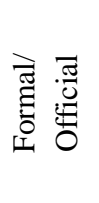 & 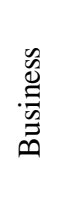 & 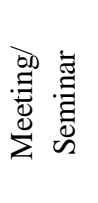 & 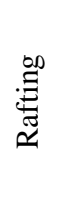 & 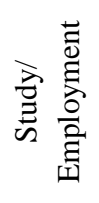 & $\frac{\mathscr{\Xi}}{\tilde{\Xi}}$ & 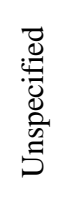 & 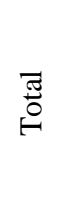 \\
\hline 2009 Mid-Jan & 29.6 & 21.0 & 9.0 & 8.6 & 4.6 & 1.4 & - & - & 19.9 & 5.9 & 100 \\
\hline 2010 Mid-Jan & 27.6 & 26.1 & 10.1 & 4.8 & 4.5 & 2.0 & 0.1 & - & 36.6 & 7.9 & 100 \\
\hline 2011 Mid-Jan & 43.8 & 11.6 & 16.8 & 4.4 & 3.5 & 1.6 & 0.1 & 0.8 & 7.7 & 9.6 & 100 \\
\hline 2012 Mid-Jan & 57.8 & 11.7 & 8.7 & 3.3 & 2.4 & 1.5 & 0.3 & 0.7 & 4.1 & 9.6 & 100 \\
\hline 2013 Mid-Jan & 47.3 & 13.1 & 13.7 & 3.8 & 3.1 & 1.7 & 0.2 & 2.4 & 9.5 & 11.4 & 100 \\
\hline 2014 Mid-Jan & 51.5 & 12.8 & 9.0 & 4.7 & 3.5 & 2.0 & 0.2 & 1.3 & 6.8 & 8.3 & 100 \\
\hline 2015 Mid-Jan & 50.1 & 12.3 & 12.5 & 4.1 & 3.1 & 1.7 & 0.2 & 1.3 & 5.3 & 9.4 & 100 \\
\hline 2016 Mid-Jan & 71.6 & 2.2 & 2.8 & 4.0 & 3.9 & 1.7 & 1.72 & 2.8 & 9.3 & - & 100 \\
\hline 2017 Mid-Jan & 65.0 & 8.8 & 11.0 & 2.83 & 3.23 & 1.7 & - & - & 7.4 & - & 100 \\
\hline 2018 Mid-Jan & 70.0 & 8.0 & 15.0 & - & - & - & - & - & 7.0 & - & 100 \\
\hline 2019 Mid-Jan & 60.0 & 16.0 & 14.4 & - & - & - & - & - & 9.6 & - & 100 \\
\hline
\end{tabular}

Source:-Economic Survey 2018/19, Ministry of Finance, Government of Nepal.

The above table shows that the majority of tourists visited Nepal with the purpose of entertainment and the number has reached above 50 percent after the year 2014. The number of tourist arrivals in Nepal with the purposes of entertainment has been rapidly increasing in the successive periods except than the year 2010 and 2013, and reached to 71.6 percent in the year 
2016. The number of tourist arrival with this purpose decreased in the year 2017 and 2019 which recordedto 65 percent and 60 percent respectively. In the year 2009, out of the total tourist arrivals, 29.6 percent of tourist visited Nepal, with the purpose of entertainment, followed by 21 percent trekking/ mountaineering, 9 percent pilgrimage, 8.6 percent formal/official, 4.6 percent business, etc. The number of tourist arrivals to Nepal with the purpose of Trekking/ Mountaineering and Pilgrimage heavily decreased in the year 2016 which may have been the consequence the earthquake in 2015. In the year 2019, out of the total tourist arrivals, 60 percent of the tourists visited with the purpose of entertainment, 16 percent for Trekking/ Mountaineering, 14.4 percent for pilgrimage, and 9.6 percent for others.

The percentage share describing the purpose of visit of tourists during the year 2019 has been picturized in the below given Pie-Diagram:

\section{Purpose of Visit}

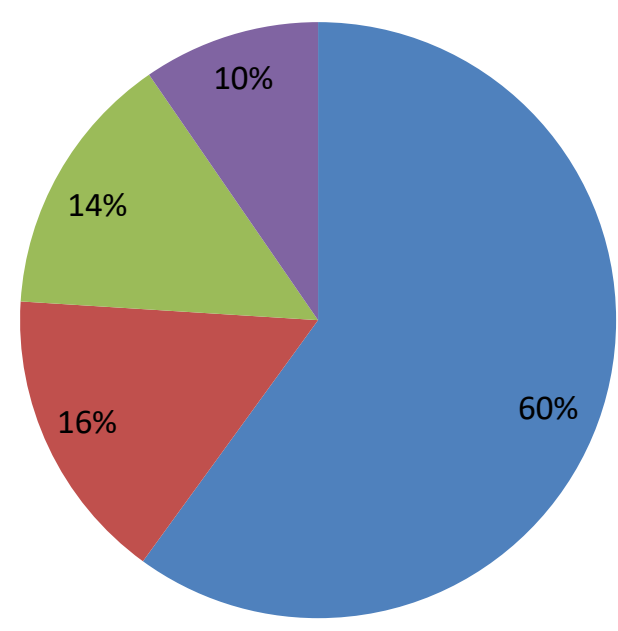

Entertainment

- Trekking / Mountaineering

Pilgrimage

- Others

\section{FOREIGN CURRENCY EARNING BY TOURISM}

In many developing countries like Nepal, the tourism sector has become a major source of foreign exchange earnings due to weak export trade. There can bea well possibility of earning foreign currency if supported by natural beauty, ancient art and culture and related factors. Any country that has surplus of foreign currency is able to invest in expansion of economic strength. According to the World Bank, in the year 2018, the country USA received 256145 million dollar, France received 73125 million dollar, and Spain received 81250 million dollar earning from 
International Journal of Social Science and Economic Research

ISSN: 2455-8834

Volume: 05, Issue: 09 "September 2020"

tourism sector in 2018. Similarly, India received 29143 million dollar, Sri Lanka received 5608 million dollar, and Bangladesh received 357 million dollar.

\section{Foreign Currency Earnings from the Tourism Sector}

\begin{tabular}{|c|c|c|c|c|c|c|c|}
\hline $\begin{array}{c}\text { Fiscal } \\
\text { Year }\end{array}$ & $\begin{array}{c}\text { Foreign } \\
\text { CurrencyEarnedfromTourism } \\
\text { Sector (Rs. in Million) }\end{array}$ & $\begin{array}{l}\text { Ratio of } \\
\text { Total } \\
\text { Export } \\
\text { ofGoods } \\
\text { (in } \\
\text { Percent) }\end{array}$ & $\begin{array}{c}\text { Ratio of } \\
\text { Total } \\
\text { Export of } \\
\text { Goods } \\
\text { andServices } \\
\text { (in } \\
\text { Percent) }\end{array}$ & $\begin{array}{c}\text { Ratio } \\
\text { ofTotalForeignCurrency } \\
\text { Earned(in percent) }\end{array}$ & $\begin{array}{l}\text { Ratio of } \\
\text { GDP } \\
\text { (in } \\
\text { Percent) }\end{array}$ & $\begin{array}{l}\text { Average } \\
\text { expenditure } \\
\text { per visitor } \\
\text { (In USD) }\end{array}$ & $\begin{array}{c}\text { Average } \\
\text { expenditure per } \\
\text { Visitor per day } \\
\text { (in USD) }\end{array}$ \\
\hline 2007/08 & 18653 & 30.1 & 17.9 & 6.2 & 2.3 & 860.3 & 73.0 \\
\hline 2008/09 & 27960 & 40.0 & 22.8 & 7.0 & 2.8 & 798.9 & 70.6 \\
\hline 2009/10 & 28139 & 44.5 & 24.6 & 6.7 & 2.4 & 578.6 & 45.7 \\
\hline 2010/11 & 24611 & 35.8 & 20.2 & 5.5 & 1.8 & 522.9 & 39.9 \\
\hline 2011/12 & 30704 & 37.7 & 20.0 & 5.1 & 2.0 & 440.8 & 36.2 \\
\hline 2012/13 & 34211 & 39.8 & 18.9 & 4.8 & 2.0 & 538.0 & 42.8 \\
\hline 2013/14 & 46375 & 45.9 & 20.5 & 5.2 & 2.4 & 597.6 & 48.0 \\
\hline 2014/15 & 53429 & 54.4 & 21.6 & 5.3 & 2.5 & 790.0 & 63.0 \\
\hline 2015/16 & 41765 & 55.8 & 19.6 & 4.0 & 1.9 & 902.4 & 68.57 \\
\hline 2016/17 & 58527 & 71.3 & 24.3 & 4.5 & 2.3 & 695.0 & 53.0 \\
\hline 2017/18 & 67095 & 71.9 & 24.8 & 5.0 & 2.2 & $680.4 *$ & $54.0 *$ \\
\hline $2018 / 19 * *$ & 47585 & 66.5 & 24.3 & 4.8 & - & - & - \\
\hline Average & - & 49.48 & 21.63 & 5.34 & 2.24 & 673.17 & 54.07 \\
\hline
\end{tabular}

Source:-Economic Survey 2018/19, Ministry of Finance, Government of Nepal and Nepal Tourism Statistics 2017 of MocTca * First six month, ** First eight month,

The foreign currency amounting to NPR 18653 million was earned from tourism sector in the year 2007/08 in Nepal, which was 6.2 percent of total foreign currency earned, and 2.3 percent of GDP. It is shown in the table that the foreign currency earnings from tourism had slowly increased except in the year 2010/11 and 2015/16, and reached to NPR 67095 million in the year 2017/18. This amountclaimed a share of 71.9 percent of the total amount of foreign currency earned through export of goods, 24.8 percent of the total foreign currency earned through the total export of goods and services, 5 percent of total foreign currency earned, and 2.2 percent of GDP. The foreign currency NPR 47585 million has been earned through tourism in the MidMarch of 2018/19, which is 66.5 percent of total export of goods, 24.3 percent of total export of goods and services, and 4.8 percent of total foreign currency earned. Other important indicators of foreign currency earnings are the expenditure per visitor per day and expenditure per visitor. If these expenditures rise, then the foreign currency earnings from tourism will also rise. In Nepal, the average expenditure per visitor per day was 73 dollar in 2007/08, and the expenditure amount had been decreasing from the year 2007/08 and reached to 42.8 dollar in2012/13. Thereafter, it increased for coming two years, and then it again decreased to 53 dollar in 2016/17, whereas, in Sri Lanka, the expenditure per visitor per day remained 173.8 Dollarin 2018. 
The comparative data describing the foregin currency earnings from the tourism in the respective fiscal years are illustrated in the following bar diagram:

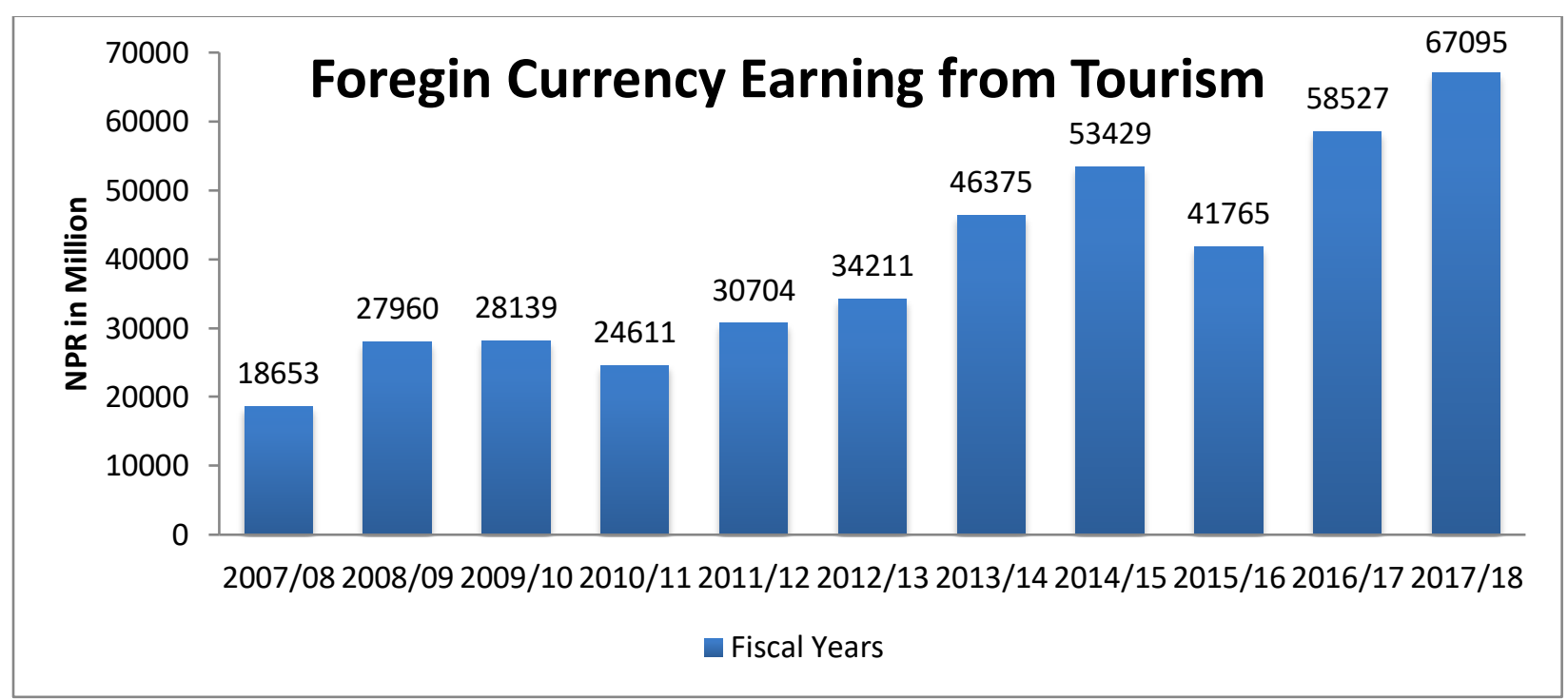

\section{CONTRIBUTION ON EMPLOYMENT BY TRAVEL AND TOURISM}

Travel and Tourism sector contributes to generate employment opportunities directly and indirectly. The direct employment opportunities are defined as the job opportunities provided by these sectors directly. These types of employment opportunities can be illustrated as the job provided by tourist hotels and restaurants, home stay, travel and trekking agencies, civil aviation, rafting and boating, paragliding, etc. There are large numbers of skilled and semi-skilled manpower needed to work in these sectors. Similarly, travel and tourism sector providesemployment opportunities in an indirect way also. Indirect employment opportunities includes the activities such as restaurant suppliers, construction companies, aircraft manufactures, handicrafts producers, marketing agencies, farming and food supply, etc. Overall, a total of 138148 persons are estimated to be directly employed in tourism industries in the year 2013. The figure suggested that one employment is generated from every 6 tourist visits in Nepal (MoCTCA, 2014). According to the World Travel and Tourism Council, China is the top country by direct contribution of travel and tourism to employment in the world. As of 2018, direct contribution of travel and tourism to employment in China was 28660.2 thousand persons that accounts for 22.85 percent of world direct contribution. India is in the second position with 26741.7 thousand persons, followed by USA with 5793.4 thousand persons in the third position in 2018. The trend of direct contribution to employment through travel and tourism sector in Nepal is presented below: 
International Journal of Social Science and Economic Research

ISSN: 2455-8834

Volume: 05, Issue: 09 "September 2020"

\section{Direct Contribution to Employment by Travel and Tourism in Nepal}

$\begin{array}{ccccc}\text { Years } & \begin{array}{c}\text { No. of Employment } \\ \text { (In Thousand } \\ \text { Persons) }\end{array} & \begin{array}{c}\text { Change in } \\ \text { Employment (in } \\ \text { Percent) }\end{array} & \begin{array}{c}\text { Contribution on } \\ \text { Total Employment } \\ \text { (in Percent) }\end{array} & \begin{array}{c}\text { Change in Total } \\ \text { Employment (in } \\ \text { Percent) }\end{array} \\ 2008 & 394.8 & 19.31 & 3.2 & 17.75 \\ 2009 & 417.1 & 5.67 & 3.3 & 3.68 \\ 2010 & 352.1 & -15.59 & 2.8 & -17.30 \\ 2011 & 434.0 & 23.26 & 3.3 & 19.93 \\ 2012 & 395.9 & -8.78 & 2.9 & 11.38 \\ 2013 & 421.5 & 6.47 & 3.0 & 3.40 \\ 2014 & 435.6 & 3.34 & 3.1 & 0.51 \\ 2015 & 428.5 & -1.62 & 2.9 & -4.10 \\ 2016 & 452.3 & 5.68 & 3.0 & 2.96 \\ 2017 & 472.3 & 4.30 & 3.1 & 2.08 \\ 2018 & 453.9 & 3.91 & 2.9 & -6.05 \\ \text { Average } & - & 4.18 & 3.05 & 3.42\end{array}$

Source:- World Travel and Tourism Council Data, 2018.

According to above table, the direct contribution of travel and tourism to employment fluctuated substantially in successive periods. The travel and tourism sector contributed 394.8 thousand persons on direct employment in 2008 and reached to 453.9 thousand persons in 2018. The contribution on employment through these sector increased by an average of 4.18 percent. Similarly, the contribution of travel and tourism sector on total employment averaged at 3.05 percent. The contribution on total employment by Travel and tourism had increased by an average rate of 3.42 percent in the period 2008 to 2018.

\section{CONCLUSION}

The tourism has been an important economic sector for the generation of income as well as foreign exchange and employment in Nepal. Being a landlocked and small mountainous country, there are some obstacles in the development of industry and export trade, especially in the 


\section{International Journal of Social Science and Economic Research}

ISSN: $2455-8834$

Volume: 05, Issue: 09 "September 2020"

overseas countries. But, Nepal holds great potential for tourism development. The major potentialities are natural beauty with Mount Everest and other Himalayan peaks, ancient art and culture, religious places with birth place of Gautam Buddha, cultural varieties, historical and cultural villages, bio-diversity with rare wildlife, various rivers, lakes and waterfalls, cities with pleasant climates like Kathmandu and Pokhara, etc. Some of the major tourism activities in Nepal are mountain climbing, trekking, sightseeing, jungle safari, rafting, boating, paragliding, bungee jumping, etc.

The tourism activities in Nepal mainly began after the establishment of democracy in 1951. A total 6179 foreign tourists had visited to Nepal in the year 1962. Thereafter, the trend of international tourists visiting to Nepal has been increasing and reached to 1173072 persons in Mid-January of 2019which is an increment of 232854 from 2018. Among the number of tourist arrivals in 2019, total of 969287had used air services and it accounted for82.63 percent of the total tourist arrivals, and rest of the 17.37 percent of the tourist had taken land services. The tourists arriving by using air services increased by 1.74 percent from 2018 . The average length of stay of tourist in Nepal was 12.4 days in the same period. India, China, America, Sri Lanka and UK are the top 5 countries in Nepal in 2019 in terms of tourist arrivals. A total of 194323 tourists visited to Nepal from India in 2019 that is 16.57 percent of the total tourist arrivals, while 153633 Chinese tourists visited to Nepal and put China in second position. In the year 2019, out of total tourist arrival, 60 percent tourists visited with the purpose of entertainment, 16 percent for Trekking/ Mountaineering, 14.4 percent for pilgrimage, and 9.6 percent for others. In 2019, the tourist arrival in Nepal with the purpose of entertainment decreased by 10 percent compared to the year 2018 .

The foreign currency earnings from tourism has slowly increased and reached to NPR 67095 million in the year 2017/18. This amount is 71.9 percent of earning through export of goods, 24.8 percent of earning through export of goods and services, 5 percent of total foreign currency earning, and 2.2 percent of the GDP.According to Travel and Tourism Council Data, the travel and tourism sector is also a major contributor in the generation of employment in Nepal. The travel and tourism sector contributed 453.9 thousand persons on direct employment in 2018, which is 2.9 percent of total employment. But, in this year 2020, the travel and tourism sector has been badly affected by widespreadCOVID -19, and there is no doubt that the loss and imbalance created will take some time to heal up.

Generally, the tourism activities in Nepal are running well with great potential and prospects, but there has been no major increment in the major tourism indicators of prosperous tourism, such as growth rate of tourist arrival, average length of stay, expenditure per tourist per day, etc. Therefore, in order to promote the travel and tourism sector, related stakeholders ought to reform basic infrastructures and other facilities and ensure proper hospitality and security for the 
International Journal of Social Science and Economic Research

ISSN: 2455-8834

Volume: 05, Issue: 09 "September 2020"

tourists. In recent years, more than 60 percent tourist visited to Nepal with the purpose of Leisure/entertainment, so the recreational facilities should be improved and extended. More tourist destination areas should be explored and made accessible and developmodern facilities where possible.

\section{REFFERENCES}

Adhikari,S. (2020). Prospect of Tourism in Nepal: A Study of Pokhara City, available at https://www.theseus.com/10024/165831.

Baral, K.(2020). Possibility of Tourism in Nepal available at https://www.nepalvisitors.com. 37656737.

Basnet,B. (2010). Challenges of Tourism Marketing in Nepal: Global and Regional Perspective, Tribhuvan University jouranal, Vol. XXVII, Research Division, T.U. Kathmandu.

Bhatia, A.K (2003). Tourism development principles and practice. New Delhi: Sterling Publication.

Gautam, B. P. (2015). Economic Impact of Tourism Finance in Nepal: Tourism and Economic Growth in Nepal Economic Review. Nepal Rastra Bank, Kathmandu, Nepal.

Ministry of Finance (MOF),(2019). Economic Survey 2018/19, Singha Durbar, Kathmandu: Ministry of Finance, Government of Nepal.

Pant,M.P. and Bist, P.S. (2018). Tourism, Importance, Prospects and Challenges: with Special Reference to Nepal available at andjournalin.com

Paudyal, S.R. (2012). Does tourism really matter for economic growth? Evidence from Nepal, Economic Review, Nepal Rastra Bank.

Lucas, R. (2004). Employment Relations in the Hospitality and Tourism Industries.Routledge: Taylor \& Francis Group. London, UK.

Ministry of Culture, Tourism and Civil Aviation (MoCTCA), (2020). Nepal Tourism Statistics 2017, 2019, Kathmandu, Government of Nepal.

Ministry of Culture, Tourism and Civil Aviation (MoCTCA), (2014).Tourism Employment survey 2014, Kathmandu, Government of Nepal.

Pradhan, I.K. (1979). Travel and Tourism Perspective, Nepal Research Group, Kathmandu, Nepal. 
International Journal of Social Science and Economic Research

ISSN: 2455-8834

Volume: 05, Issue: 09 "September 2020"

Pradhan, K.M. (1977). Planning Tourism in Nepal, Bikas Publishing House, New Delhi, India.

Shrestha, H.P. and Shrestha, P. (2012). Tourism in Nepal : A Historical Perspective, Present Trend of Development, Himalayan Journal of Sociology \& Anthropology, Vol. V .

Subedi, B.K. (2018). Prospects of Tourism in Nepalese Economy, available at:https://www.academia.edu/37656737.

Website:

https://www.unwto.org

https://www.wttc.org 